\title{
Pengembangan Industri Kecil dan Rumah Tangga Alas Kaki dalam Menuju Keberlanjutan Usaha dan Menghadapi China-ASEAN Free Trade Agreement
}

\author{
Small and Household Footwear Industries Development toward Business Sustainability and Facing the \\ China-ASEAN Free Trade Agreement
}

Ma'mun Sarma $^{1}$, Farida Ratna Dewi ${ }^{1}$, dan Edward H Siregar ${ }^{1}$

${ }^{1}$ Departemen Manajemen, Fakultas Ekonomi dan Manajemen, Institut Pertanian Bogor

Jl. Kamper, Kampus IPB Darmaga, Bogor 16680

\begin{abstract}
ABSTRAK
Industri alas kaki merupakan salah satu sektor industri kecil dan menengah yang didukung pemerintah nasional, namun pengembangan usaha pada industri ini masih relatif rendah. Berbagai kebijakan yang telah dilakukan pemerintah terkait pengaturan ekspor dan impor tampaknya belum memberikan manfaat nyata bagi perkembangan industri alas kaki nasional. Kondisi tersebut semakin diperparah dengan diberlakukannya CAFTA (China-ASEAN Free Trade Agreement) di Indonesia. Minimnya kesiapan industri lokal dalam menghadapi berbagai produk China di dalam negeri, dikhawatirkan dapat menekan daya saing produk lokal menjadi semakin lemah. Oleh karena itu, tujuan penelitian ini menganalisis faktor-faktor yang memengaruhi upaya pengembangan industri kecil dan kerajinan rumah tangga alas kaki, serta mengetahui pengaruh CAFTA pada keberlanjutan usaha industri kecil dan kerajinan rumah tangga alas kaki. Penelitian ini dilakukan di Bogor (kabupaten dan kota) yang merupakan salah satu sentra alas kaki di Indonesia. Contoh penelitian adalah industri kecil dan rumah tangga unggulan yang diambil secara purposive cluster sampling dengan responden 100 orang. Data dianalisis dengan mempergunakan statistik deskripitif dan Structural Equation Modelling (SEM) Hasil SEM menunjukkan bahwa upaya pengembangan industri kecildan kerajinan rumah tangga alas kaki dipengaruhi secara langsung oleh motivasi usaha dari para pengusaha dan kebijakan pemerintah yang mampu memfasilitasi para pengusaha pada industri ini. Peningkatan pada pengembangan usaha berpengaruh nyata pada keberlanjutan usaha, di mana keberlanjutan usaha juga dipengaruhi secara langsung oleh karakteristik dari pengusaha yang mampu mengoptimalkan produktivitasnya dan penerapan CAFTA yang direspon dengan kemampuan daya saing yang baik dari industri lokal bersangkutan.
\end{abstract}

Kata kunci: alas kaki, industri kecil dan rumah tangga, CAFTA, keberlanjutan usaha

\begin{abstract}
Although the footwear industry is one sector of the small and medium industries which supported by the government, but the development of the industry is still relatively low. Various government policies have been made related to export and import settings, however the policies do not seem to provide significant benefits to the national development of the footwear industry. The condition is further exacerbated by the implementation of CAFTA (China-ASEAN Free Trade Agreement) in Indonesia. The lack of preparedness of local industry in the face of Chinese products in the country is feared to suppress the competitiveness of local products become increasingly weak. Therefore, the main objective of this study is to analyze the factors that influence the development efforts of small and household footwear industries and to analyze the effect of CAFTA on the sustainability of small and household footwear industries. The research was conducted in Bogor (district and city) which is a center of footwear industry in Indonesia. The respondent of the study consists of the leading small and household industries
\end{abstract}

\footnotetext{
*) Korespondensi:

Jl. Kamper, Kampus IPB Darmaga, Bogor 16680; e-mail: mamun_sarma@yahoo.com
} 
taken by purposive sampling with 100 respondents. Data were analyzed using the statistical descripitive and Structural Equation Modeling (SEM). Based on SEM analysis, the results indicate that efforts to develop small and household footwear industries directly affected by motivation efforts of the entrepreneurs in this industry and the government policies that facilitate the entrepreneurs in this industry. Increasing the development of business sustainability is also directly influenced by the characteristics of the entrepreneurs who are able to optimize productivity and the CAFTA implementation which is responded by good competitiveness from the local industry.

Key words: footwear, small and household industries, CAFTA, business development

\section{PENDAHULUAN}

Industri alas kaki adalah salah satu industri yang menjanjikan di masa mendatang bagi pertumbuhan perekonomian Indonesia dan termasuk dalam prioritas yang dikembangkan sesuai dengan Rencana Pembangunan Jangka Menengah Nasional (Peraturan Presiden No. 7/2005). Saat ini Indonesia memiliki sekitar 368 perusahaan industri alas kaki dengan kapasitas produksi 1,18 milyar pesanan per tahun dan terdapat 84 sentra industri kecil yang memproduksi alas kaki. Keberadaan industri kecil alas kaki tersebut berperan penting dalam perolehan devisa dan memperkokoh struktur industri nasional (Hubeis, 1997), khususnya melalui pemanfaatan dan pengembangan potensi sumber daya alam (SDA) yang dimiliki Indonesia.

Rantai industri yang cukup panjang menyebabkan jumlah usaha pendukung pada industri alas kaki ini cukup banyak. Perkembangan industri pendukung alas kaki di Indonesia ditunjukkan dengan adanya 100 perusahaan industri penyamakan kulit dengan kapasitas produksi 144 juta per tahun yang menjadi pemasok bahan baku bagi industri alas kaki nasional. Selain itu, kini telah berkembang industri kulit imitasi atau sintetis dengan mutu baik sebagai bahan baku bagi industri alas kaki non kulit, serta berkembangnya industri pendukung dan komponen seperti las/acuan, lem/perekat, tekstil, tali sepatu, retsluiting, sol (dalam dan luar) dan elastic band.

Meskipun keberadaan industri alas kaki, terutama industri kecil dan rumah tangga alas kaki sangat menjanjikan bagi perekonomian Indonesia, namun dalam pengembangannya industri ini masih mengalami berbagai masalah. Beberapa kebijakan yang dilakukan pemerintah seperti: pengenaan Pajak Ekspor (PE) terhadap kulit mentah dan setengah jadi guna mengamankan pasokan bahan baku (kulit) untuk industri alas kaki, serta menaikkan tarif bea masuk alas kaki melalui pengaturan Nomor
Pokok Importir Khusus (NPIK) dalam rangka pengamanan dan pengembangan pasar dalam negeri, tampaknya belum memberikan manfaat yang signifikan bagi perkembangan industri alas kaki nasional.

Belum tuntasnya berbagai permasalahan internal tersebut di atas, kini para pelaku usaha kecil dan industri rumah tangga alas kaki juga harus dihadapkan dengan berbagai efek dari kesepakatan Indonesia dan perdagangan bebas CAFTA (China-ASEAN Free Trade Agreement). CAFTA merupakan salah satu kawasan perdagangan bebas terbatas (Hutabarat et al 2007). CAFTA telah berlaku sejak 1 Januari 2010 (Sekretariat Negara RI, 2012). Maraknya produk China yang lebih murah dibandingkan produk lokal, berpotensi menekan daya saing industri lokal dan mematikan pasar dalam negeri, karena industri bersangkutan belum siap untuk bersaing, maka Utami (2007) merekomendasikan dua hal dalam strategi pengembangan usaha pengrajin, yaitu: (1) peningkatan mutu perilaku usaha dan kemandirian usaha dan (2) adanya kelembagaan usaha dengan dukungan dari pemerintah daerah, organisasi non profit (ornop) dan Perguruan Tinggi.

Tujuan penelitian ini:

1. Mengkaji karakteristik pengrajin dan profil industri kecil dan rumah tangga alas kaki.

2. Menelaah masalah secara umum keadaan industri kecil dan rumah tangga alas kaki.

3. Menyusun model keberlanjutan industri kecil dan kerajinan rumah tangga alas kaki dan mengetahui pengaruh CAFTA terhadap keberlanjutan industri kecil dan kerajinan rumah tangga alas kaki.

\section{METODOLOGI}

Penelitian ini didasari oleh pengamatan pada berbagai fenomena strategik yang terjadi di masyarakat, seperti globalisasi dan perdagangan bebas CAFTA. Pada penelitian ini ada beberapa 
peubah yang diamati dan dianalisis pengaruhpengaruhnya. Peubah-peubah tersebut adalah peubah bebas $\left(\mathrm{X}_{1}-\mathrm{X}_{4}\right)$, peubah intervening $\left(\mathrm{Y}_{1}\right)$ dan peubah terikat $\left(\mathrm{Y}_{2}\right)$. Hubungan antar masingmasing peubah tersebut dapat dijabarkan pada Gambar 1.

Untuk mengetahui kaitan pengaruh antara peubah penelitian maka dirumuskanlah hipotesis kerja sebagai berikut:

1. Karakteristik industri kecil/pengrajin $\left(X_{1}\right)$ berpengaruh nyata dan positif terhadap pengembangan usaha $\left(\mathrm{Y}_{1}\right)$ dan secara tidak langsung berpengaruh nyata dan positif terhadap keberlanjutan usaha industri kecil dan kerajinan rumah tangga $\left(\mathrm{Y}_{2}\right)$.

2. Karakteristik usaha $\left(X_{2}\right)$ berpengaruh nyata dan positif terhadap pengembangan usaha $\left(\mathrm{Y}_{1}\right)$ dan secara tidak langsung berpengaruh nyata dan positif terhadap keberlanjutan usaha industri kecil dan kerajinan rumah tangga $\left(\mathrm{Y}_{2}\right)$.

3. Motivasi usaha $\left(X_{3}\right)$ berpengaruh nyata dan positif terhadap pengembangan usaha pengrajin $\left(\mathrm{Y}_{1}\right)$ dan secara tidak langsung berpengaruh nyata dan positif terhadap keberlanjutan usaha industri kecil ( $\left.\mathrm{Y}_{2}\right)$.

4. Intervensi kebijakan pemerintah $\left(X_{4}\right)$ berpengaruh nyata dan positif terhadap pengembangan usaha pengrajin $\left(\mathrm{Y}_{1}\right)$ dan secara tidak langsung berpengaruh nyata dan positif terhadap keberlanjutan usaha industri kecil dan kerajinan rumah tangga $\left(\mathrm{Y}_{2}\right)$

5. Penerapan CAFTA $\left(X_{5}\right)$ berpengaruh nyata dan positif terhadap pengembangan usaha pengrajin $\left(\mathrm{Y}_{1}\right)$ dan secara tidak langsung berpengaruh nyata dan positif terhadap keberlanjutan usaha industri kecil ( $\left.\mathrm{Y}_{2}\right)$.

Penelitian ini berlokasi di Kecamatan Ciomas untuk mewakili Kabupaten Bogor dan Kecamatan Bogor Selatan untuk mewakili Kota Bogor. Penelitian dilakukan dalam kurun waktu 3 bulan (Juni-Agustus 2012), dengan obyek penelitian adalah industri kecil dan rumah tangga yang menghasilkan produk unggulan alas kaki di wilayah Bogor.

Populasi penelitian adalah seluruh industri kecil dan rumah tangga unggulan di wilayah Bogor. Contoh penelitian adalah industri kecil dan rumah tangga unggulan yang diambil secara purposive cluster sampling dengan responden 100 orang pelaku usaha yang mewakili industri kecil dan rumah tangga alas kaki pada sentra alas kaki Bogor (di kabupaten dan kota Bogor).

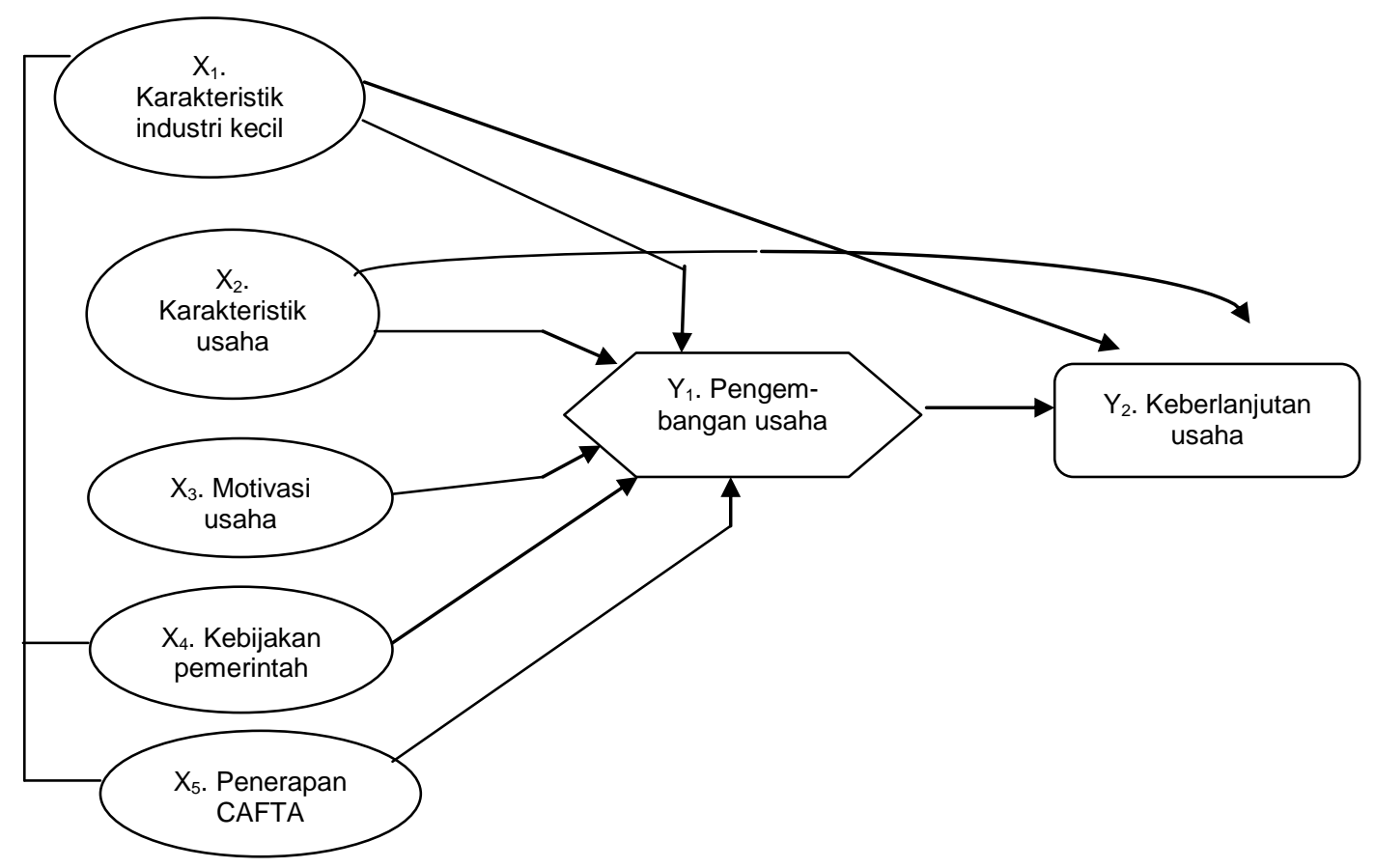

Gambar 1. Kerangka Pemikiran Penelitian 


\section{Pengumpulan Data}

Pengumpulan data primer yang bersifat kuantitatif diperoleh secara langsung melalui informasi yang diberikan oleh responden industri kecil. Data tersebut dikelompokan berdasarkan peubah-peubah yang diteliti, lalu dijelaskan dengan berbagai data kualitatif, baik dari responden industri kecil maupun dari instansi atau pihak terkait. Metode pengumpulan data yang digunakan adalah melalui penyebaran kuesioner/ angket, observasi lapangan, wawancara (indepth interview), studi dokumentasi dan membuat lembar penilaian.

\section{Pengolahan dan Analisis Data}

Dari hasil wawancara dengan menggunakan kuesioner, data penelitian diolah dengan beberapa teknik analisis berikut: (1) analisis statistik deskriptif digunakan untuk melihat distribusi atau sebaran kategori peubah-peubah yang diteliti, (2) analisis structural equation modelling (SEM) untuk melihat pengaruh langsung dan tak langsung antar peubah penelitian, serta sekaligus merumuskan model yang sesuai untuk pengembangan industri kecil dan keberlanjutan usaha dalam menghadapi CAFTA, dan (3) analisisis deskriptif-kualitatif untuk memperjelas makna dari temuan penelitian.

\section{HASIL DAN PEMBAHASAN}

\section{Karakteristik Pengrajin Industri Kecil dan Rumah Tangga Alas Kaki}

Pada umumnya, pelaku usaha alas kaki Bogor merupakan lulusan Sekolah Dasar/ Madrasah Ibtidaiyah (SD/MI) 47\%. Hal ini sesuai dengan rataan lama sekolah pelaku usaha alas kaki yang baru mencapai enam tahun. Hasil serupa juga diperoleh pada data pendidikan formal suami atau istri pelaku usaha, di mana $52 \%$ darinya merupakan tamatan SD/MI. Disadari atau tidak, pendidikan formal berperan penting dalam pengembangan usahanya. Pendidikan yang kurang menunjang telah mengakibatkan lemah-nya posisi pelaku usaha alas kaki, sehingga rentan terhadap penipuan dan kerugian. Kesadaran akan pentingnya menempuh pendidikan formal yang lebih tinggi ditunjukkan dengan kepedulian pelaku usaha yang mulai membekali anak-anaknya dengan pendidikan formal pada jenjang Sekolah Menengah Pertama/Madrasah Tsanawiyah (SMP/MTs) 21\%, Sekolah Menengah Atas/Sekolah Menengah Kejuruan/Madrasah Ali- yah (SMA/SMK/MA) sejumlah 20\%, hingga Perguruan Tinggi (2\%).

Para pelaku usaha alas kaki di wilayah Bogor sebagian besar (48\%) adalah mantan buruh di bengkel-bengkel sepatu/sandal di Jakarta, Tangerang dan Bogor. Dengan bermodalkan pengalaman yang dimiliki dan keyakinan bahwa usaha alas kaki berpotensi menguntungkan, telah membuatnya beralih mendirikan usaha alas kaki secara mandiri. Sebagian besar pelaku usaha merupakan mantan buruh di bengkel-bengkel alas kaki dengan kemampuan yang baik dalam membuat alas kaki maka tingkat keikutsertaannya dalam mengikuti kursus sangat rendah (6\%). Namun, bagi pelaku usaha yang mengikuti kursus, keikutsertaannya dalam kursus dirasa bermanfaat (67\%) bagi usahanya.

Banyak hal yang melatarbelakangi para pelaku usaha alas kaki dalam menjalankan bisnisnya. Mayoritas latar belakang menjalankan usaha alas kaki adalah keinginan sendiri (65\%) demi memenuhi kebutuhan anggota keluarga yang menjadi tanggungan, yang rataannya berjumlah empat orang (35\%). Meski sebagian besar pelaku usaha sudah cukup lama menekuni usaha ini, yaitu lebih dari 10-20 tahun (42\%), namun karakter usaha alas kaki sebagai usaha turun temurun tidak terlihat nyata pada penelitian ini, di mana 73\% pelaku usaha memulai usahanya dengan tidak mengikuti keluarga atau murni merintis sendiri.

\section{Profil Industri Kecil dan Rumah Tangga Alas Kaki}

Jenis usaha pada industri alas kaki di wilayah Bogor tergolong pada industri kecil (54\%). Hal ini sesuai dengan rataan jumlah pekerja yang dimiliki pelaku usaha, yaitu 5 orang pekerja, waktu kerja 8-12 jam kerja per hari, dengan omset rataan 100-250 kodi per bulan (53\%). Dikarenakan jenis usaha yang masih tergolong industri kecil, maka mayoritas darinya mengalami kekurangan dalam alat produksi $(58 \%)$, modal $(51 \%)$ dan sumber daya manusia (64\%). Keterbatasan modal membuatnya lebih memilih sebagai pengrajin yang menggunakan sistem "bon putih" daripada berusaha secara mandiri.

Berbagai keterbatasan sumber daya dan tingkat pendidikan relatif rendah, membentuk pola pikir pelaku usaha pada orientasi jangka pendek, di mana $76 \%$ darinya mengaku tidak pernah keluar daerah dalam menjalankan usahanya. Tidak dapat dipungkiri bahwa 
berbagai keterbatasan yang dihadapi dalam usaha ini membuat pengusaha kurang semangat dalam menekuni usahanya (51\%), namun karena tidak memiliki keahlian di bidang usaha lain telah membuat mayoritas darinya jarang (37\%) berkeinginan untuk pindah usaha.

Usaha alas kaki memiliki posisi yang berbeda-beda bagi para pelakunya. Berdasarkan data yang diperoleh diketahui bahwa usaha alas kaki ini menjadi sumber utama pendapatan keluarga (70\%). Hal ini dapat dimengerti, karena sebagian besar pelaku usaha alas kaki (87\%) tidak memiliki usaha lain atau usaha sampingan. Usaha alas kaki di wilayah Bogor juga merupakan tumpuan hidup bagi mayoritas pelakunya, dimana sebagian besar pelaku usaha (67\%) menyatakan bahwa 76 hingga $100 \%$ kebutuhan keluarga, terpenuhi melalui pendapatan dari usaha alas kaki. Pemenuhan pendapatan dapat dicapai melalui kemampuan mengelola modal yang baik dari para pengusaha, dimana $75 \%$ darinya mampu mengelola modalnya secara produktif dan hemat.

Selain faktor internal dari pelaku usaha, faktor eksternal juga berperan penting dalam membentuk profil industri alas kaki Bogor. Beberapa modal sosial yang mampu mendukung pelaku usaha untuk berkembang meliputi sebagian besar masyarakat sekitar berkeyakinan pada keberlanjutan usahanya $(58 \%)$, sebagian besar masyarakat sekitar berkeyakinan bahwa kerja tulus adalah ibadah (79\%), adanya sikap saling bantu antar pengusaha kecil (83\%), adanya intensitas yang sering dalam hal saling menghargai antar pengusaha kecil (54\%) dan adanya intensitas yang sering dalam hal saling berkomunikasi antar pengusaha kecil saat menghadapi tantangan (66\%).

Berdasarkan karakteristik dan kendala yang dihadapi industri kecil/rumah tangga alas kaki, maka upaya pengembangannya dilakukan melalui strategi peningkatan daya saing usaha seperti pendekatan kelompok dan membangun jaringan usaha yang saling terkait menuju pendekatan klaster (Widyastutik et al., 2010). Namun, hingga saat ini hal tersebut belum dapat terealisasi, mengingat keberadaan kelompok usaha yang belum terkoordinasi dengan baik, sehingga sebagian besar pelaku usaha (95\%) tidak dapat mengidentifikasi eksistensi dari kelompok usaha di lingkungannya.

Keberadaan kelompok pengusaha kecil yang kurang-tidak mengutamakan kemajuan bersama $(61 \%)$ dan kurang-tidak memiliki kesamaan tentang perlunya mutu produk $(54 \%)$, membuat sebagian besar pengusaha $(75 \%)$ menganggap bahwa keberadaan kelompok kerjasama tersebut kurang bermanfaat bagi kemajuan usahanya. Permasalahan ini merupakan cerminan dari kurang optimalnya fungsi Kosebo (Koperasi Sandal Sepatu Bogor), yang notabene berperan dalam mengkordinasikan kelompok usaha. Minimnya kekompakan antar pelaku usaha, pada akhirnya akan menyebabkan persaingan yang tidak sehat dalam industri ini. Oleh karena itu, dalam rangka mendorong industri alas kaki berkelanjutan, Pemerintah berkewajiban menjalankan perannya, baik sebagai fasilitator dan regulator dengan tepat sasaran.

\section{Analisis SEM: Model Pengembangan Industri Kecil dan Rumah Tangga Alas Kaki dalam Menuju Keberlanjutan Usaha dan Menghadapi China-ASEAN Free Trade Agreement}

Sebelum dilakukan analisa lebih lanjut terhadap model yang telah diperoleh, terlebih dahulu diidentifikasi evaluasi kesesuaian model tersebut. Berdasarkan pengujian kesesuaian model melalui empat kriteria goodness of fit (Tabel 1), yaitu chi-square, Root Mean Square Error of Approximation (RMSEA), Goodness of Fit Index (GFI) dan Comparative Fit Index (CFI) diketahui bahwa modelyang ada dapat dikatakan cukup baik dan cocok atau fit dengan data yang dikumpulkan, sehingga dapat dilakukan analisa lanjutan terhadap model tersebut (Bagozzi dan Fornell dalam Ghozali dan Fuad, 2005; dan Wijanto, 2008).

Tabel 1. Hasil pengujian kelayakan model pada analisis CFA (Confirmatory Factor Analysis) peubah eksogen

\begin{tabular}{lclcc}
\hline Goodness of Fit & Cut of value & \multicolumn{1}{c}{ Rentang standar nilai } & Hasil Olah Data & Keterangan \\
\hline Chi Square & Nilai kecil & Di bawah nilai tabel & 102,99 & Moderate fit \\
RMSEA & $\leq 0,08$ & Nilai yang lebih kecil menunjukkan & 0,15 & Moderate fit \\
GFI & $\geq 0,90$ & close fit & 0,84 & Close fit \\
CFI & $\geq 0,95$ & Mendekati 1 berarti a very good fit & 0,82 & Close fit \\
\hline
\end{tabular}

Sumber: Data primer, diolah (2012). 
Model pengembangan menuju keberlanjutan usaha industri kecil dan kerajinan rumah tangga alas kaki pada Gambar 2 menunjukkan beberapa indikator dominan yang mampu mencerminkan masing-masing peubah latennya. Peubah karakteristik industri memiliki beberapa indikator utama yang terdiri atas: (1) indikator jumlah pekerja yang dimiliki, (2) indikator jenis usaha dan (3) indikator rataan omset (Rp) per bulan. Di sisi lain, peubah karakteristik usaha memiliki indikator dominan, yaitu indikator karakteristik usaha industri rumah tangga/kecil dan (4) indikator faktor eksternal pengusaha industri rumah tangga/kecil. Selanjutnya, untuk beberapa peubah laten lainnya, masing-masing hanya memiliki satu indikator dominan, yaitu peubah laten motivasi usaha dengan indikator motivasi pengusaha industri rumah tangga/kecil, peubah laten pengembangan usaha dengan indikator pengembangan usaha, peubah laten keberlanjutan usaha dengan indikator keberlanjutan usaha, peubah laten kebijakan pemerintah dengan indikator kebijakan pemerintah dan peubah laten penerapan CAFTA dengan indikator penerapan CAFTA.

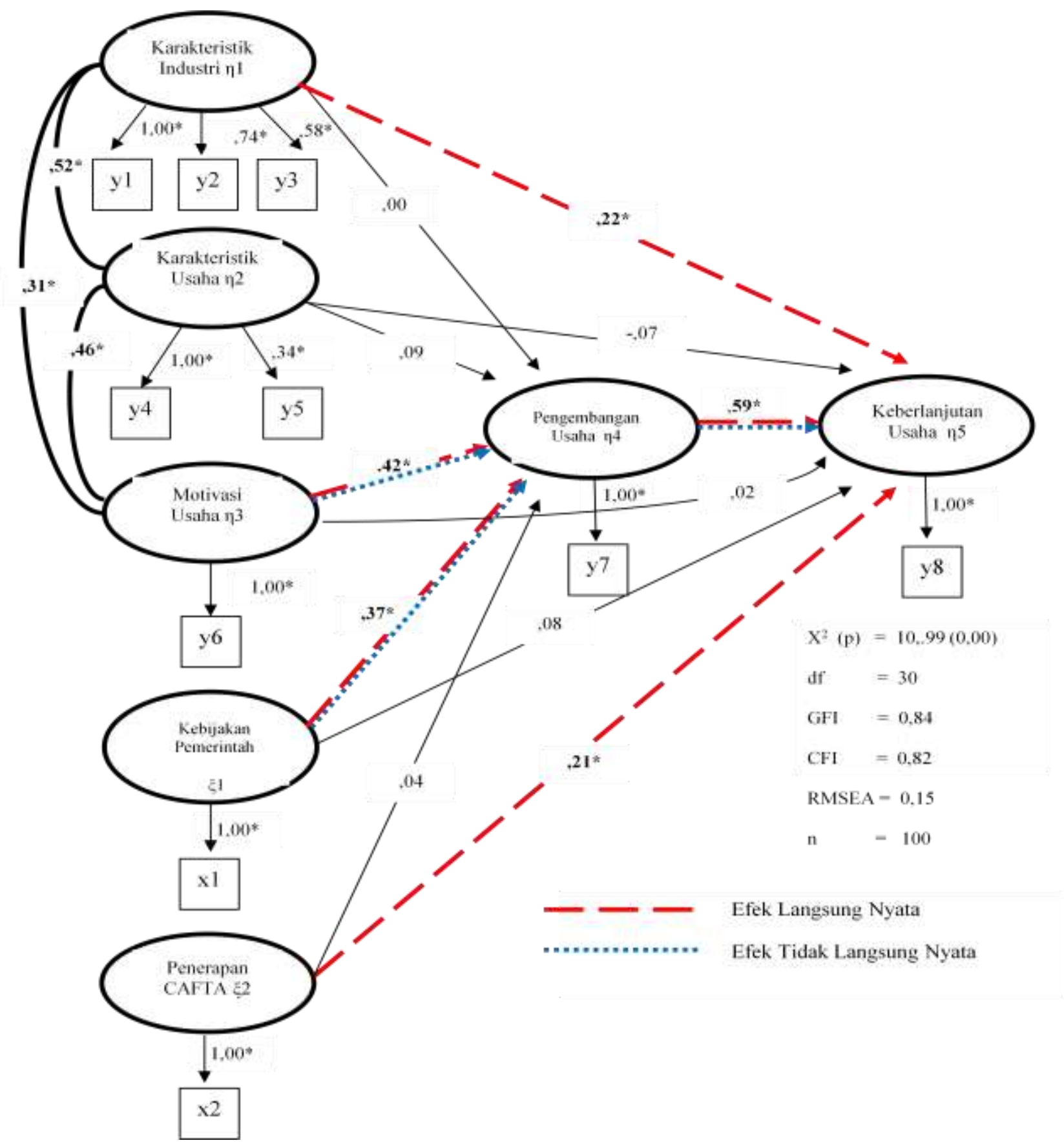

Gambar 2. Model SEM Faktor-faktor yang mempengaruhi keberlanjutan usaha industri rumah tangga/kecil (n=100) 
Selain terdapat beberapa pengaruh langsung yang nyata antar peubah laten, didapatkan juga bentuk pengaruh tidak langsung yang nyata pada model ini. Besaran nilai dari masing-masing efek atau pengaruh selengkapnya disajikan pada Tabel 2. Berdasarkan analisis SEM yang menyangkut hasil dekomposisi efek (Tabel 2), hasil penelitian menunjukkan bahwa:

1. Peubah laten motivasi usaha dari pengusaha industri rumah tangga/kecil berpengaruh secara langsung terhadap peubah laten pengembangan usaha $\left(\beta=0,42^{*}\right)$.

2. Peubah laten kebijakan pemerintah berpengaruh secara langsung terhadap peubah laten pengembangan usaha $\left(\beta=0,37^{*}\right)$.

3. Peubah laten karakteristik industri berpengaruh secara langsung terhadap peubah laten keberlanjutan usaha $\left(\beta=0,22^{*}\right)$.

4. Peubah laten penerapan CAFTA berpengaruh secara langsung terhadap peubah laten keberlanjutan usaha $\left(\beta=0,21^{*}\right)$.

5. Peubah laten pengembangan usaha berpengaruh secara langsung terhadap peubah laten keberlanjutan usaha $\left(\beta=0,59^{*}\right)$.

6. Peubah laten motivasi usaha berpengaruh secara tidak langsung terhadap peubah laten keberlanjutan usaha melalui peubah pengembangan usaha $\left(\beta=0,25^{*}\right)$.

7. Peubah laten kebijakan pemerintah berpengaruh secara tidak langsung terhadap peubah laten keberlanjutan usaha melalui peubah pengembangan usaha $\left(\beta=0,22^{*}\right)$.

Secara umum diketahui bahwa pengembangan usaha dipengaruhi secara langsung oleh motivasi usaha dari para pengusaha dan kebijakan pemerintah yang mampu memfasilitasi para pengusaha industri rumah tangga/kecil ini. Dalam hal ini, peningkatan pengembangan usaha memainkan peranan penting dalam membentuk keberlanjutan berusaha. Dengan demikian, penelitian ini membuktikan bahwa pengembangan usaha yang dilakukan oleh pengusaha merupakan mediating variable (peubah perantara) atau sasaran antara untuk mencapai keberlanjutan usaha, melalui motivasi yang gigih dari pengusaha dan keberadaan kebijakan pemerintah yang pro terhadap industri ini.

Setelah proses tersebut berjalan dengan berkesinambungan, maka keberlanjutan usaha dari para pengusaha ini akan dipengaruhi secara langsung oleh karakteristik dari pengusaha yang mampu mengoptimalkan produktivitasnya, varia- si jenis usaha dan menjaga kestabilan omset. Hal lainnya, keberlanjutan usaha tersebut diperkuat lagi melalui pengaruh penerapan CAFTA pada industri ini.

Pada dasarnya, keberadaan CAFTA memiliki dampak positif dan negatif perdagangan secara umum (Faisol, 2012) dan hal ini berlaku juga terhadap industri alas kaki, usaha untuk menghadapi CAFTA dan peningkatan daya saing, yang dicerminkan dari peningkatan pengembangan usaha yang baik mutlak diperlukan. Keberadaan CAFTA yang direspon dengan kesiapan yang baik dari daya saing industri lokal, sebenarnya akan memberikan dampak positif pada perkembangan industri lokal. Pemberlakuan CAFTA akan memaksa produsen lokal untuk bersaing dan berinovasi, sehingga pada akhirnya akan tercipta peningkatan perkembangan usaha pada sektor tersebut. Selain itu, melalui kemampuan daya saing yang baik dan kemampuan dalam hal standarisasi produk, akan mempermudah produk-produk lokal untuk memasuki pasar China.

Jika dilihat dari nilai total effect (TE), pada Tabel 2 diketahui, bahwa faktor yang paling berpengaruh terhadap pengembangan usaha adalah motivasi usaha dari para pengusaha sendiri $\left(0,42^{*}\right)$ dan diikuti oleh kebijakan pemerintah $\left(0,37^{*}\right)$. Faktor yang paling berpengaruh terhadap keberlanjutan usaha adalah pengembangan usaha $\left(0,59^{*}\right)$ disusul oleh kebijakan pemerintah $\left(0.29^{*}\right)$, motivasi usaha $\left(0.27^{*}\right)$, penerapan CAFTA $\left(0.23^{*}\right)$ dan karakteristik industri $\left(0.22^{*}\right)$.

Keberadaan motivasi internal dari pengusaha dan kebijakan pemerintah memainkan peranan penting dalam menunjang pengembangan usaha, yang nantinya akan membentuk keberlanjutan usaha. Agar tetap mampu bertahan dan berkelanjutan, pelaku industri kecil/rumah tangga alas kaki perlu meningkatkan kemampuan daya saingnya, baik pada daya saing IKM maupun daya saing produknya. Kunci peningkatan daya saing terletak pada kompetensi pelaku usaha yang tercermin dari motivasi pengusaha untuk berkembang, juga didukung oleh peran pemerintah melalui kebijakan-kebijakan pemerintah yang pro terhadap kemajuan industri alas kaki, sehingga mampu menunjang pengembangan dan keberlanjutan usaha pada industri ini.

Penerapan CAFTA pada industri alas kaki di Bogor ternyata memberikan pengaruh nyata dan positif terhadap kelanjutan usaha. Pada dasarnya CAFTA dapat dipandang sebagai peluang untuk perluasan pasar bagi usaha yang 
Tabel 2. Hasil dekomposisi efek Gambar 1

\begin{tabular}{|c|c|c|c|}
\hline \multirow{2}{*}{ Peubah } & \multicolumn{3}{|c|}{ Total } \\
\hline & TE & DE & IE \\
\hline \multicolumn{4}{|l|}{ Pengembangan Usaha $\eta_{4}$} \\
\hline 1. Karakteristik Industri $\eta_{1}$ & 0,00 & 0,00 & 0,00 \\
\hline 2. Karakteristik Usaha $\eta_{2}$ & 0,09 & 0,09 & 0,00 \\
\hline 3. Motivasi Usaha $\eta_{2}$ & $0,42^{*}$ & $0,42^{*}$ & 0,00 \\
\hline 4. Kebijakan Pemerintah $\xi_{1}$ & $0,37^{*}$ & $0,37^{*}$ & 0,00 \\
\hline 5. Penerapan CAFTA $\xi_{2}$ & 0,04 & 0,04 & 0,00 \\
\hline \multicolumn{4}{|l|}{ Keberlanjutan Usaha $\eta_{5}$} \\
\hline 1. Karakteristik Industri $\eta_{1}$ & $0,22 *$ & $0,22 *$ & 0,00 \\
\hline 2. Karakteristik Usaha $\eta_{2}$ & $-0,02$ & 0,07 & 0.05 \\
\hline 3.Motivasi Usaha $\eta_{2}$ & $0,27^{*}$ & 0,02 & $0.25^{*}$ \\
\hline 4. Kebijakan Pemerintah $\xi_{1}$ & $0,29 *$ & 0,07 & $0.22^{*}$ \\
\hline 5. Penerapan CAFTA $\xi_{2}$ & $0,23^{*}$ & $0,21^{*}$ & 0.02 \\
\hline 6. Pengembangan Usaha $\eta_{4}$ & $0,59 *$ & $0,59 *$ & 0.00 \\
\hline
\end{tabular}

Keterangan: TE = Total Effect $($ Efek Total), DE = Direct Effect (Efek Langsung), IE = Indirect Effect (Efek Tidak Langsung)

telah melakukan kegiatan usahanya dengan efisien dan berdaya saing tinggi. Dalam hal ini kebijakan Pemerintah juga memberikan pengaruh nyata dan positif terhadap kelanjutan usaha. Dengan demikian, pengaruh positif penerapan CAFTA ini tentunya perlu mendapatkan perhatian dari kebijakan pemerintah yang sekaligus juga untuk keberlanjutan usaha industri alas kaki. Kusumawati et al, (2010) menyatakan bahwa secara spesifik dan operasional, pemerintah berkewajiban menjadi fasilitator dalam akses permodalan, menjadi regulator dalam melindungi usaha alas kaki melalui kebijakan baik di tingkat input (modal dan bahan baku), hingga kebijakan di tingkat pemasaran. Hampir seluruh negara di dunia termasuk negara-negara maju (USA, Germany, France, England dan sebagainya) memberi kebijakan yang jelas mengenai perlindungan dan perlakuan (scheme) terhadap usahausaha kecil dan menengah mereka (Koesoema, 2002).

\section{KESIMPULAN}

Berdasarkan hasil analisis dalam pembahasan, maka dapat disimpulkan:

1. Karakteristik pelaku usaha alas kaki di Bogor secara umum termasuk pada kelompok dengan tingkat pendidikan relatif rendah dengan mindset jangka pendek, tetapi memiliki keahlian sangat baik dalam memproduksi alas kaki, karena usaha ini masih dijadikan usaha pokok sumber utama pendapatan keluarga.

2. Secara umum, permasalahan yang terjadi pada pelaku usaha adalah permodalan, sehingga sebagian besar darinya lebih memilih sebagai pengrajin yang menggunakan sistem "bon putih" daripada berusaha secara mandiri.

3. Upaya pengembangan industri kecil dan kerajinan rumah tangga alas kaki dipengaruhi secara langsung oleh motivasi usaha dari para pengusaha dan kebijakan pemerintah yang mampu memfasilitasi para pengusaha pada industri ini; peningkatan pengembangan usaha berpengaruh nyata pada keberlanjutan berusaha; keberlanjutan usaha juga dipengaruhi secara langsung oleh karakteristik dari pengusaha yang mampu mengoptimalkan produktivitasnya dan penerapan CAFTA yang direspon dengan kemampuan daya saing yang baik.

\section{UCAPAN TERIMA KASIH}

Ucapan terima kasih disampaikan kepada Direktorat Jenderal Pendidikan Tinggi, Kemendikbud, yang telah memberikan dana hibah Penelitian Strategis Nasional Tahun Anggaran 2012 untuk pelaksanaan penelitian ini.

\section{DAFTAR PUSTAKA}

Faisol, M. 2012. Dampak AFTA ASEAN-China pada Perekonomian Indonesia. http://ishals .student.umm.ac.id/2012/02/03/dampakafta-asean-china-pada-perekonomianindonesia/ (akses Mei 2013). 
Ghozali I, Fuad. 2005. Structural Equation Modelling Teori, Konsep, dan Aplikasi dengan Program Lisrel 8.45. Badan Penerbit Universitas Diponegoro, Semarang.

Hubeis, M. 1997. Menuju Industri Kecil Profesional di Era Globalisasi melalui Pemberdayaan Manajemen Industri. Orasi Ilmiah Guru Besar Tetap Ilmu Manajemen Industri Fakultas Teknologi Pertanian IPB.

Hutabarat, B., M.H. Sawit, S.K. Dermoredjo, Wahida, H.J. Purba dan S. Nuryanti. 2007. Analisis Kesepakatan Perdagangan Bebas Indonesia-China dan Kerjasama AFTA dan Dampaknya terhadap Perdagangan Komoditas Pertanian Indonesia. Pusat Analisis Sosial Ekonomi dan Kebijakan Pertanian, Balitbangtan, Departemen Pertanian.

Koesoema, B. W. 2002. Indonesia dalam proses Globalisasi berkaitan dengan kesiapan menghadapi AFTA, strategi pemberdayaan UKM (Usaha Kecil dan Menengah) dan Penegakan System Hukum (ekonomi)/ "Law Enforcement" Dalam Dialog Publik Strategi Pemberdayaan Usaha Kecil Menengah dalam Menghadapi AFTA Melalui Penegakan Sistem Hukum Ekonomi Indonesia dalam rangka Dies Natalis Universitas Airlangga Surabaya, 4 November 2002.
Kusumawati, R., H. Siregar, S. Budiharsono, W.A. Ridwan. 2010. Analisis Kebijakan Pengembangan Ekonomi Lokal Industri Alas Kaki yang Berkelanjutan di Kabupaten Bogor. Forum Pascasarjana, Vol. 33, No.3, Juli 2010, hal 165-176.

Sekretariat Negara RI. 2010. ACFTA sebagai Tantangan Menuju Perekonomian yang Kompetitif (http://www.setneg.go.id).

Utami, H.N. 2007. Keberdayaan, Kemajuan dan Keberlanjutan Usaha Pengrajin: Kasus Kabupaten Sidoarjo dan Kabupaten Magetan Provinsi Jawa Timur. Disertasi Sekolah Pascasarjana IPB.

Widyastutik, M. H., Putri EIK. 2010. Analisis Faktor-faktor yang mempengaruhi Pengembangan Klaster UMKM Alas Kaki di Kota Bogor yang Berdaya Saing. Jurnal Manajemen dan Agribisnis, Vol. 7, No. 1, Maret 2010, hal 16-26.

Wijanto, S. H.. 2008. Structural Equation Modeling dengan LISREL 8.8 Konsep dan Tutorial. Graha Ilmu. Yogyakarta. 